\title{
Gliricidia leaf meal and multi-enzyme in rabbits diet: effect on performance, blood indices, serum metabolites and antioxidant status
}

Olugbenga David Oloruntola1*, Johnson Oluwasola Agbede², Simeon Olugbenga Ayodele ${ }^{3}$, Eyanlola Soladoye Ayedun ${ }^{3}$, Olajumoke Temidayo Daramola ${ }^{3}$ and Deborah Adebukola Oloruntola ${ }^{4}$

\begin{abstract}
Background: Following the ban on the importation of import-dependent fed ingredients in most developing countries, the need to look inward for local content is now compelling. Thus, leaf meals that have phytogenic additive potentials are envisaged will be a viable feed ingredient in rabbit diets.

Methods: The effect of dietary inclusion of gliricidia leaf meal (GLM) with or without multi-enzyme (E) supplementation in rabbits was investigated using ninety-six 35-day old rabbits of crossbreed (Newzealand and Chinchilla). One basal diet that met the requirements of growing rabbit was formulated (Diet 1). Thereafter, another two diets were formulated to contain 15\% GLM and 15\% GLM plus multi-enzyme at $1 \mathrm{~g} / \mathrm{kg}$ and designated as diets 2 and 3 respectively. The rabbits were randomly distributed into the 3 diets (32 rabbits/treatment; 4 rabbits/ replicate) and fed their respective experimental diets for 8 weeks.

Results: The body weight and daily weight gain of the rabbits fed on GLM free diet and those on GLM-based diets (diets 1 and 2) were similar at finishing period of 63-91 day but have lower $(P<0.01)$ values than those rabbits fed GLM + E based diet (diet 3) at finishing period (63-91 days) and whole fattening period (35-91 days). The apparent dry matter and crude protein digestibility of rabbits fed control diet and those fed 15\% GLM based diet were lower $(P<0.05)$ than those fed 15\% GLM + E-based diet. Triglycerides concentration of rabbits fed 15\% GLM-based diet without enzyme addition were lower $(P<0.05)$ than those observed for rabbits on the rest test diets. Cholesterol and Low-Density Lipoprotein levels of rabbits fed 15\% GLM and 15\% GLM + E-based diets were lower $(P<0.05)$ than those fed the GLM free diet. The superoxide dismutase and glutathione peroxidase of rabbits fed the GLM free diet (diet 1) were significantly $(P<0.05)$ lower than those fed the 15\%GLM and 15\% GLM + E-based diets.

Conclusion: Dietary inclusion of GLM at 15\% of the diet did not have a negative effect on the rabbits postweaning period (35-63 days) but will require multi-enzyme supplementation to enhance growth indices at finishing period (63-91 day) without precipitating negative effect on the rabbits' health status.
\end{abstract}

Keywords: Leaf meals, Rabbits, Exo-enzyme, Performance, Health status

\footnotetext{
* Correspondence: oloruntoladavid@gmail.com;

olugbenga.oloruntola@aaua.edu.ng

${ }^{1}$ Animal Science Department, Adekunle Ajasin University, Akungba Akoko,

Nigeria

Full list of author information is available at the end of the article
}

(C) The Author(s). 2018 Open Access This article is distributed under the terms of the Creative Commons Attribution 4.0 International License (http://creativecommons.org/licenses/by/4.0/), which permits unrestricted use, distribution, and reproduction in any medium, provided you give appropriate credit to the original author(s) and the source, provide a link to the Creative Commons license, and indicate if changes were made. The Creative Commons Public Domain Dedication waiver (http://creativecommons.org/publicdomain/zero/1.0/) applies to the data made available in this article, unless otherwise stated. 


\section{Background}

The use of plants in different forms as alternatives to the relatively expensive and scarce conventional feed resources in the production of monogastric animals is becoming more popular in the tropics. This is because these plants and their parts could serve as an indispensable source of protein, phytobiotics and antioxidants in monogastric nutrition $[1,2]$. Some phytochemicals in plants improve antioxidant, anti-microbial, feed flavour and palatability which could result in increased feed intake and performance in animals [3]. These tropical plants are available because of their rapid growth which is enhanced by the prevailing and environmental factors. Their dietary inclusion in form of meals is capable of reducing the cost of commercial feeds, with a resultant reduction in the cost of animal protein and improvement in animal health $[2,4,5]$.

Gliricidia (Gliricidia sepium) provide large quantities of high-quality biomass all year round; contain high-quality protein and minerals in adequate concentration [5, 6]. Gliricidia leaves have also been reported to contain compounds such as flavonoids, polyphenolics and saponin [7] which could serve as drawbacks/ feed ingredients in compounding their use as animal feeds at relatively high inclusion level. However, the addition of exogenous enzymes is envisaged could help alleviate the deleterious effects of these secondary metabolites an animal [8], improve nutrient availability [9], reduce ileal flow and mortality of the rabbits [10].

The effects of nutrition on performance traits and haematological traits $[11,12]$ and the general wellbeing of an animal cannot be underscored. Effect of some herbs on general performance, nutrient utilization, antioxidants, haematological indices and serum enzymes in monogastric animals have been documented [2]. However, report on the effect of gliricidia leaf meal on growth indices, blood and serum metabolite as well as the antioxidant status in the rabbit is rear when the diet is supplemented with exo-enzyme. The later thus formed the basis for this study.

\section{Methods}

\section{Experimental site}

The experimental procedures involving animals were approved by the Agricultural Technology Department Research and Ethics Committee, The Federal Polytechnic, Ado Ekiti, Nigeria. This study was carried out at the Livestock Unit of the Teaching and Research Farm of The Federal Polytechnic, Ado Ekiti, Nigeria. The experimental site is $437 \mathrm{~mm}$ above sea level and on latitudes $7^{\circ} 37^{\circ} \mathrm{N}$ and longitude $5^{\circ} 11^{\circ} \mathrm{E}$, with the annual temperature of $26.2^{\circ} \mathrm{C}$ and the annual rainfall of $1247 \mathrm{~mm}$ [13].

\section{Preparation of leaf meal and experimental diets}

Fresh gliricidia leaves were harvested within the precinct of The Federal Polytechnic, Ado Ekiti, Nigeria. The leaves were air dried for 3 weeks and milled using hammer mill (3.0 $\mathrm{mm}$ sieve) to make Gliricidia leaf meal (GLM). Thereafter, the GLM was analyzed for the proximate composition using the methods of AOAC [14] and tannin using the procedure described by Markkar and Goodchild [15]. The gross energy was determined with combustion calorimeter (Model:e2k combustion calorimeter, www.cal2k.com). The commercial enzyme (Biozyme $\mathrm{PH}$ ) used was procured from a reputable vendor in Ado Ekiti, Nigeria. It was manufactured by Biomix S.A, Carrera 47C, Sabaneta-Colombia and has a minimum of cellulase (700,000 U.A), phytase (1,200F.T.U), protease $(8,000,000 \quad$ U.P), $\alpha$-amylase $(800,000 \quad$ U.A $)$, $\beta$-glucanase (300,000 U.BG), lipase (20,000 U.I) and xylanase (500,000 U.X). A basal diet (Diet 1) was formulated to meet the minimum requirement of a growing rabbit $(16.88 \%$ crude protein, $17.59 \%$ crude fibre and $2670.52 \mathrm{Kcal} / \mathrm{kg}$ Metabolizable energy). Another diet was formulated to include 15\% GLM and balanced for crude protein, crude fibre and metabolizable energy. This diet was thoroughly mixed and divided into two portions. The first portion was designated Diet 2 while the second portion was supplemented with $1 \mathrm{~g} / \mathrm{kg}$ of the commercial enzyme and designated Diet 3 . All the diets were pelletized ( $4 \mathrm{~mm}$ in diameter and $8 \mathrm{~mm}$ long). The compositions of the experimental diets are shown in Table 1.

\section{Animal, housing and experimental procedure}

Ninety-six, 35-day old weaner rabbits (32 rabbits/ treatment; 4 rabbits/replicate) of cross-breed (New-Zealand and Chinchilla) of equal sexes and weighed $675.03 \pm 8.02$ g were randomly distributed to 3 dietary treatments. The rabbits were housed in galvanized wire meshed cages $(60 \times 60 \times 30 \mathrm{~cm})$ in a well-ventilated pen and fed ad libitum throughout the experimental period (56 days) with their respective experimental diets. The rabbits were managed in line with the recommendations and guidelines for applied nutrition experiments in rabbits [16]. The body weight and feed consumption of the rabbits were determined and recorded on 7 days interval and used to calculate the daily weight gain and feed conversion ratio. Also, the mortality was checked daily. At 45 days into the trial, eight (8) rabbits were selected randomly from each dietary group and caged individually in metabolism cages $(55 \times 35 \times 26 \mathrm{~cm})$. The rabbits were adapted for 7 days and thereafter, hard faeces were collected from them daily into polythene bags at approximately 08:00 $\mathrm{h}$ each morning before serving daily ration for 
Table 1 Composition of experimental diet (\%)

\begin{tabular}{|c|c|c|c|}
\hline & $\begin{array}{l}\text { Diet } 1 \\
\text { 0\%GLM } \\
\end{array}$ & $\begin{array}{l}\text { Diet } 2 \\
15 \% G L M \\
\end{array}$ & $\begin{array}{l}\text { Diet } 3 \\
15 \% \mathrm{GLM}+\mathrm{E}\end{array}$ \\
\hline \multicolumn{4}{|l|}{ Ingredients (\%) } \\
\hline Maize & 8.00 & 6.00 & 6.00 \\
\hline Wheat offals & 8.00 & 7.00 & 7.00 \\
\hline Soybean meal & 16.10 & 10.80 & 10.80 \\
\hline Maize husk & 22.00 & 21.00 & 21.00 \\
\hline Gliricidia leaf meal & 0.00 & 15.00 & 15.00 \\
\hline Cassava peels & 22.00 & 20.00 & 20.00 \\
\hline Brewers dried grain & 21.70 & 18.00 & 18.00 \\
\hline Bone meal & 1.10 & 1.10 & 1.10 \\
\hline Premix & 0.25 & 0.25 & 0.25 \\
\hline Methionine & 0.20 & 0.20 & 0.20 \\
\hline Lysine & 0.10 & 0.10 & 0.10 \\
\hline Salt & 0.25 & 0.25 & 0.25 \\
\hline Vegetable oil & 0.30 & 0.30 & 0.30 \\
\hline \multicolumn{4}{|l|}{ Determined analysis (\%) } \\
\hline Crude protein & 16.88 & 16.91 & 16.89 \\
\hline Crude fibre & 17.59 & 17.93 & 17.95 \\
\hline Neutral detergent fiber & 39.18 & 38.91 & 38.95 \\
\hline Acid detergent fiber & 17.59 & 17.22 & 1726 \\
\hline Acid detergent lignin & 3.68 & 6.65 & 6.62 \\
\hline aMetabolizable energy (Kcal/kg) & 2670.52 & 2670.56 & 2670.56 \\
\hline
\end{tabular}

${ }^{a}$ Calculated analysis

4 days. The faeces were stored in a freezer $\left(-18{ }^{\circ} \mathrm{C}\right)$ until chemical analysis. On day 55 of the experiment, 2 rabbits per cage (16 rabbits per diet) were selected, tagged, starved overnight, weighed and sacrificed (at approximately 8:00 $\mathrm{h}$ in the morning) as described by Blasco et al. [17]. The skin, limb and head were removed before evisceration of the carcass. The dressing weight and weights of the internal organs (lungs, kidney, liver, heart and spleen) were determined. Thereafter, the dressing percentage and the relative weights of the internal organs were calculated as the percentage of slaughter weight.

On day 56 of the experiment, blood samples were collected from the marginal ear vein of the rabbits (2 rabbits/cage; 16 rabbits/diet) as described by Brunett et al. [18]. Each blood sample collected (about $7 \mathrm{ml}$ ) was divided into two. One portion was placed in potassium ethylene diamine tetraacetic acid (KEDTA) sample tube (for haematology) and the other in the plain tube (for serology and antioxidant enzyme determination). Thereafter, Shenzhen Mind ray Auto Haematology Analyser (Model Bc-3200, Shenzhen Mind ray Biomedical Electronics Co. Hamburg 20,537, Germany) was used to determine the haematological indices while the serum chemistry indices were determined with a Reflectron - Plus 8C79 (Roche Diagnostic, GonbH Mannheim, Germany) using kits. Glutathione peroxidase (GPx) activity and superoxide dismutase (SOD) in serum sample were determined as earlier described by Rotruck et al. [19] and Misra and Fridovich, [20], respectively. Catalase activity was also determined as previously described by Aebi, [21].

\section{Chemical and statistical analyses}

The three diets were analysed for their crude protein and crude fibre as described by AOAC [14]. The neutral detergent fibre, acid detergent fibre and acid detergent lignin were also determined [22]. Data generated in the animal trial were analyzed using SPSS 2011 package (version 20) following standard procedure for analysis of variance. Statistical significance was assessed at $(P<0.05)$ while the means were separated using Duncan multiple range test of the same statistical package.

\section{Results}

Table 2 shows that the body weight (BW), daily weight gain (DWG), daily feed intake (DFI) and feed conversion ratio (FCR) of rabbits fed the control diet (GLM free diet) were not significantly $(P>0.05)$ different from those fed the test diets at postweaning period (35-63d). However, the BW of the rabbits on the control diet and those on $15 \%$ GLM without exo-enzyme (E) supplementation were statistically similar but have lower $(P<0.01)$ value than those fed 15\% GLM + E at finishing (63-91 days) and whole fattening period (35-91 days).

Table 3 shows that only apparent digestibility (AD) of the dry matter (DM) and crude protein $(\mathrm{CP})$ were significantly $(P<0.05)$ influenced by the dietary treatment. For instance, while the apparent $\mathrm{DM}$ digestibility of rabbits fed the GLM free diet (64.30\%) and $15 \%$ GLM-E (67.11\%) supplemented diet were similar $(P>0.05)$, the AD of the DM of those rabbits fed $15 \%$ GLM were significantly $(P<0.05)$ lower (59.93\%) than those fed 15\% GLM + E diet but similar to those fed the GLM free diet (64.30\%). The same trend was also observed for the apparent $\mathrm{CP}$ digestibility. In both the $\mathrm{DM}$ and $\mathrm{CP}$ apparent digestibility, rabbits fed on the $15 \%$ GLM $+\mathrm{E}$ diet consistently had the highest values with rabbits fed on the 15\% GLM-based diet having the lowest values.

Also, Table 4 shows that the slaughter weight, hot carcass weight, commercial slaughter weight, liver, kidney, lung, heart and gallbladder of rabbits fed the GLM free diet and those fed the two test diets were not significantly $(P>0.05)$ influenced by the dietary treatment.

The mean values of the various haematological indices of rabbits studied were not significantly $(P>0.05)$ 
Table 2 Effects of Gliricidia leaf meal and exo-enzyme supplementation on performance traits of rabbits

\begin{tabular}{|c|c|c|c|c|c|}
\hline & $\begin{array}{l}\text { Diet } 1 \\
\text { 0\% GLM } \\
\end{array}$ & $\begin{array}{l}\text { Diet } 2 \\
15 \% G L M \\
\end{array}$ & $\begin{array}{l}\text { Diet } 3 \\
\text { 15\%GLM + E }\end{array}$ & SEM & $P$ value \\
\hline No of rabbits & 32 & 32 & 32 & & \\
\hline \multicolumn{6}{|c|}{ Post-weaning period (35-63 d) } \\
\hline Body weight at 35 d (g) & 672.44 & 674.88 & 677.73 & 2.67 & 0.77 \\
\hline Body weight at 63 d (g) & 1544.15 & 1582.90 & 1630.62 & 29.93 & 0.56 \\
\hline Daily weight gain (g/d) & 31.13 & 32.42 & 34.03 & 1.01 & 0.57 \\
\hline Daily feed intake $(\mathrm{g} / \mathrm{d})$ & 78.31 & 76.87 & 81.31 & 4.11 & 0.93 \\
\hline Feed conversion ratio & 2.53 & 2.41 & 2.39 & 0.15 & 0.94 \\
\hline \multicolumn{6}{|l|}{ Finishing period (63-91 d) } \\
\hline Body weight at 91 d (g) & $2171.50^{b}$ & $2239.90^{\mathrm{b}}$ & $2358.16^{a}$ & 29.42 & 0.01 \\
\hline Daily weight gain (g/d) & 22.41 & 23.46 & 25.98 & 0.99 & 0.36 \\
\hline Daily feed intake $(\mathrm{g} / \mathrm{d})$ & 82.53 & 82.19 & 90.31 & 5.44 & 0.83 \\
\hline Feed conversion ratio & 3.70 & 3.56 & 3.52 & 0.27 & 0.97 \\
\hline \multicolumn{6}{|c|}{ Whole fattening period (35-91 d) } \\
\hline Daily weight gain $(\mathrm{g} / \mathrm{d})$ & $26.76^{b}$ & $27.94^{b}$ & $30.01^{\mathrm{a}}$ & 0.51 & 0.01 \\
\hline Daily feed intake $(\mathrm{g} / \mathrm{d})$ & 77.64 & 76.79 & 82.85 & 4.51 & 0.87 \\
\hline Feed conversion ratio & 3.01 & 2.85 & 2.86 & 0.17 & 0.94 \\
\hline
\end{tabular}

Means within a row with different letters are significantly different $(P<0.05)$

GLM Gliricidia leaf meal, $E$ exogenous enzyme

different (Table 5), while the triglycerides, cholesterol and Low-Density Lipoprotein (LDL) values were significantly $(P<0.05)$ affected of the entire serum metabolites measured (Table 6). Serum triglycerides concentration of rabbits fed 15\%GLM supplemented diet were lower $(P<0.05)$ than those observed for rabbit on the rest test diets. The serum cholesterol and LDL levels of rabbits fed 15\%GLM and 15\%GLM $+\mathrm{E}$ supplemented diets were lower $(P<0.01)$ than those fed the control. Table 7 shows the effect of GLM and enzyme supplementation on the oxidative status of the experimental rabbits. The superoxide dismutase and glutathione peroxidase of rabbits fed the GLM free diet were consistently significantly $(P<$ $0.003,0.01)$ lower than those fed the $15 \%$ GLM and $\mathrm{GLM}+\mathrm{E}$ diets.

\section{Discussion}

The similarity in the performance indices of rabbits fed 15\% GLM with or without enzyme-based diets and the control diet at post-weaning period (35-63 days) in this study is a pointer to the possible suitability of gliricidia leaf meal as a good feedstuff which can be used as replacer to the import-dependent feed resources in rabbits' diets at post-weaning period. The use of leaf meals in the formulation of monogastrics' and or rabbit feeds had been identified as a helpful way of alleviating the problem emanating from competition between human and animals for some conventional feedstuff $[6,9,23]$. Furthermore, the superiority of the rabbits fed gliricidia leaf meal based diet supplemented with exogenous multi-enzyme in terms of higher

Table 3 Effects of Gliricidia leaf meal and exo-enzyme supplementation on dry matter (DM) intake and apparent digestibility (\%)

\begin{tabular}{|c|c|c|c|c|c|}
\hline & $\begin{array}{l}\text { Diet } 1 \\
0 \% \text { GLM } \\
\end{array}$ & $\begin{array}{l}\text { Diet } 2 \\
15 \% G L M \\
\end{array}$ & $\begin{array}{l}\text { Diet } 3 \\
15 \% G L M+E\end{array}$ & SEM & $P$ value \\
\hline No of rabbits & 8 & 8 & 8 & & \\
\hline Feed intake (g DM/d) & 73.38 & 71.41 & 75.43 & 1.15 & 0.41 \\
\hline Dry matter & $64.30^{\mathrm{ab}}$ & $59.93^{b}$ & $67.11^{\mathrm{a}}$ & 1.27 & 0.03 \\
\hline Crude protein & $65.62^{\mathrm{ab}}$ & $63.52^{b}$ & $66.32^{\mathrm{a}}$ & 1.00 & 0.02 \\
\hline Crude fibre & 28.99 & 28.58 & 30.26 & 0.92 & 0.79 \\
\hline Neutral detergent fibre & 47.29 & 46.53 & 48.58 & 1.04 & 0.77 \\
\hline Acid detergent fibre & 27.91 & 27.62 & 28.51 & 0.57 & 0.85 \\
\hline
\end{tabular}

Means within a row with different letters are significantly different $(P<0.05)$

GLM Gliricidia leaf meal, $E$ exogenous enzyme 
Table 4 Effects of Gliricidia leaf meal and enzyme supplementation on carcass and relative organ (\% slaughter weight) of rabbits

\begin{tabular}{|c|c|c|c|c|c|}
\hline & $\begin{array}{l}\text { Diet } 1 \\
0 \% \text { GLM } \\
\end{array}$ & $\begin{array}{l}\text { Diet } 2 \\
15 \% G L M \\
\end{array}$ & $\begin{array}{l}\text { Diet } 3 \\
15 \% \mathrm{GLM}+\mathrm{E}\end{array}$ & SEM & $P$ value \\
\hline No of rabbits & 16 & 16 & 16 & & \\
\hline Slaughter weight (g) & 1953.80 & 1966.16 & 1943.65 & 10.69 & 0.74 \\
\hline Hot carcass weight & 58.37 & 62.13 & 62.53 & 0.98 & 0.16 \\
\hline Commercial slaughter weight & 16.59 & 15.28 & 14.41 & 0.86 & 0.65 \\
\hline Liver & 3.29 & 3.19 & 3.40 & 0.04 & 0.09 \\
\hline Kidney & 0.66 & 0.60 & 0.61 & 0.01 & 0.06 \\
\hline Lung & 0.41 & 0.42 & 0.43 & 0.01 & 0.97 \\
\hline Heart & 0.23 & 0.26 & 0.23 & 0.01 & 0.64 \\
\hline Gallbladder & 0.07 & 0.04 & 0.06 & 0.01 & 0.33 \\
\hline
\end{tabular}

Means within a row with different letters are significantly different $(P<0.05)$

GLM Gliricidia leaf meal, $E$ exogenous enzyme

body weight at day 91(finishing period: 63-91d) and daily weight gain during the whole fattening period (35-91 d) support the efficacy of the exo-enzyme to enhance the utilization of the nutrients (DM and $\mathrm{CP}$ ) in the diet for better growth performance [24]. Dietary enzymes supplementation in monogastrics enhances the breaking down of compounds in animal feeds which may not be effectively broken down by the animals' own digestive enzyme and thereby improve the productivity of animals. This is achieved following the disruption of cell-matrix of fibrous feedstuffs by the exogenous enzymes; thereby giving easy access of the endogenous enzymes to digest the entrapped nutrients [25]. This result is consistent with the report of Eiben et al. [26] but the contrast with a report of Ayodele et al. [9], who reported a non-significant effect of enzyme supplementation on performance of rabbits. The observed variations in the two reports can be attributed to many factors among which are the dietary component and age of the animals [9, 27] and the enzyme composition used in the trials. The observed lower dry matter (DM) and crude protein (CP) apparent digestibility recorded in rabbits fed on 15\% GLM based diet (diet 2) when compared to those fed 15\% GLM + E based diet (diet 3) might be due to the activities of secondary metabolites (anti-nutrients) and fibre which were not sufficiently biologically degraded; as the multi-enzyme used in the current study (diet 3 ) contained varying degrees of phytase, cellulose, protease, $\alpha$-amylase, $\beta$-glucanase, lipase and zylanase activities of which their inclusion could result in increased anti-nutrients degradation and improved nutrient utilization [28]. In this study, the inclusion of $15 \%$ GLM led to $0.2 \mathrm{~g}$ tannin/100 $\mathrm{g}$ in the diets 2 and 3 (Table 8) and tannin has long been implicated in the reduction of protein utilization in animal [29]. The negative effect of this anti-nutritional factor seems to have been removed by the relatively higher crude protein digestibility value recorded in multi-enzyme supplemented diet and this is consistent with the current report of Ayodele et al. [9].

Table 5 Effects of Gliricidia leaf meal and exo-enzyme supplementation on haematological indices of rabbits

\begin{tabular}{|c|c|c|c|c|c|}
\hline & $\begin{array}{l}\text { Diet } 1 \\
0 \% \text { GLM } \\
\end{array}$ & $\begin{array}{l}\text { Diet } 2 \\
15 \% G L M\end{array}$ & $\begin{array}{l}\text { Diet } 3 \\
15 \% G L M+E\end{array}$ & SEM & $P$ value \\
\hline White blood cells $\left(\times 10^{9} / \mathrm{l}\right)$ & 7.85 & 5.79 & 7.07 & 0.41 & 0.11 \\
\hline Monocytes $\left(\times 10^{9} / \mathrm{l}\right)$ & 0.58 & 0.49 & 0.49 & 0.07 & 0.86 \\
\hline Granulocytes $\left(\times 10^{9} /\right)$ & 4.17 & 3.74 & 3.46 & 0.16 & 0.22 \\
\hline Lymphocytes $\left(\times 10^{9} / \mathrm{l}\right)$ & 3.09 & 1.55 & 3.11 & 0.39 & 0.18 \\
\hline Red blood cells $\left(\times 10^{12} / \mathrm{l}\right)$ & 5.93 & 6.44 & 6.01 & 0.16 & 0.44 \\
\hline Haemoglobin concentration ( $\mathrm{g} / \mathrm{dl})$ & 14.00 & 13.65 & 13.40 & 0.23 & 0.62 \\
\hline Packed cell volume (\%) & 39.46 & 39.96 & 38.11 & 0.81 & 0.69 \\
\hline $\mathrm{MCV}(\mathrm{fl})$ & 65.50 & 62.00 & 62.67 & 1.22 & 0.31 \\
\hline $\mathrm{MCH}(\mathrm{pg})$ & 23.65 & 21.15 & 22.13 & 0.58 & 0.23 \\
\hline $\mathrm{MCHC}(\mathrm{g} / \mathrm{dl})$ & 35.50 & 34.15 & 35.20 & 0.34 & 0.27 \\
\hline
\end{tabular}

Means within a row with different letters are significantly different $(P<0.05)$

GLM Gliricidia leaf meal, $E$ exogenous enzyme, MCV Mean cell volume, MCH Mean cell haemoglobin, MCHC Mean cell haemoglobin concentration 
Table 6 Effects of Gliricidia leaf meal and enzyme supplementation on serum metabolites of rabbits

\begin{tabular}{|c|c|c|c|c|c|}
\hline & $\begin{array}{l}\text { Diet } 1 \\
0 \% \text { GLM } \\
\end{array}$ & $\begin{array}{l}\text { Diet } 2 \\
15 \% G L M \\
\end{array}$ & $\begin{array}{l}\text { Diet } 3 \\
\text { 15\%GLM + E }\end{array}$ & SEM & $P$ value \\
\hline Total protein $(\mathrm{g} / \mathrm{l})$ & 57.80 & 59.50 & 61.55 & 1.17 & 0.48 \\
\hline Urea $(\mu \mathrm{mol} / \mathrm{l})$ & 15.25 & 11.40 & 8.92 & 1.20 & 0.07 \\
\hline Triglycerides (mg/dl) & $1.17^{\mathrm{a}}$ & $1.10^{\mathrm{b}}$ & $1.15^{\mathrm{a}}$ & 0.01 & 0.03 \\
\hline Cholesterol (mg/dl) & $5.62^{\mathrm{a}}$ & $2.93^{\mathrm{b}}$ & $3.09^{b}$ & 0.48 & 0.01 \\
\hline $\mathrm{LDL}(\mathrm{mg} / \mathrm{dl})$ & $4.44^{\mathrm{a}}$ & $0.94^{\mathrm{b}}$ & $1.70^{\mathrm{b}}$ & 0.56 & 0.01 \\
\hline $\mathrm{HDL}(\mathrm{mg} / \mathrm{dl})$ & 0.49 & 0.43 & 0.57 & 0.03 & 0.27 \\
\hline Alanine aminotransferase $(\mathrm{U} / \mathrm{L})$ & 92.20 & 60.55 & 49.60 & 8.61 & 0.09 \\
\hline Aspartate aminotransferase (U/L) & 45.45 & 51.10 & 53.85 & 2.36 & 0.38 \\
\hline Bilirubin total $(\mathrm{mg} / \mathrm{dl})$ & 11.45 & 10.52 & 12.40 & 0.48 & 0.32 \\
\hline Creatinine (mg/dl) & 66.05 & 77.55 & 73.10 & 2.79 & 0.26 \\
\hline
\end{tabular}

Means within a row with different letters are significantly different $(P<0.05)$

GLM Gliricidia leaf meal, $E$ exogenous enzyme, $L D L$ Low-density lipoprotein, $H D L$ High-density lipoprotein

Beyond reduced weight gain; animals have been reported to have an abnormal change in the weight and morphology of their internal organs as the response to toxicity situation. In this study, the slaughter weight, hot carcass weight, commercial slaughter weight and the relative weights of liver, kidney, lung, heart and gallbladder were similar across the treatment groups, suggesting that the inclusion of GLM and GLM + E promoted similar muscle and organ development and that the organ's integrity of the rabbits was not compromised. This disagreed with an earlier report of Ayodele et al. [9], that the use of Alchornea leaf meal had an effect on carcass and relative weights of the organ of growing rabbits.

Nutrition has a strong influence on the haematological traits; and values of these haematological traits are indicators of the nutritional status of the animals [30-32]. In this study, values of all the haematological indices fall within the normal range [18] and were not different across the dietary groups. Contrary to the present report, Adeyeye et al. [31] reported a variation in the haemoglobin concentration, red blood cells and mean cell volume when processed cocoa pod husk meal was fed to rabbits. Oloruntola and Ayodele [32] also reported a variation in white blood cells, lymphocytes and platelets in rabbits fed $0 \%$ and $10 \%$ pawpaw leaf meal inclusive diet. However, this present study further confirms the nutritional adequacy of the diets used in this study and in particular indicating the safety of the treatment applied in supporting the normal haemapoietic process in the experimental rabbits. Elevated and or highly elevated triglyceride level may be a risk factor for atherosclerosis, pancreatitis and liver disease. In this study, reduced level of triglycerides in rabbits fed 15\% GLM diet compared to the rest test diets signifies the possible presence of some bioactive compounds in GLM which impaired fat absorption and consequent fat depletion. This is further supported by the reduced cholesterol and Low-Density Lipoprotein level (LDL) in rabbits fed 15\%GLM and 15\%GLM + Ebased-diets compared to the control diet in this study as this is also of health benefit to the consumers, especially those predisposed to heart disease. The inclusion of GLM in the diets vis-a-vis decreased uptake of cholesterol or increased loss or catabolism of cholesterol [33] further confirms the health benefits of including GLM in rabbit's diet. The observed decreased in cholesterol level in this study may be linked to the presence of saponins, one of the components of gliricidia which exerts inhibitory effects on cholesterol uptake in the gut through intra-lumenal physiochemical interaction [29]. However, the present findings agreed with earlier reports of Oloruntola et al., [30]; Adeyeye et al. [31] and Oloruntola and Ayodele [32], who all reported a reduced cholesterol level in rabbits fed Alchornea cordifolia leaf meal based diets,

Table 7 Effects of Gliricidia leaf meal and enzyme supplementation on oxidative status of rabbits

\begin{tabular}{|c|c|c|c|c|c|}
\hline & $\begin{array}{l}\text { Diet } 1 \\
\text { 0\% GLM }\end{array}$ & $\begin{array}{l}\text { Diet } 2 \\
15 \% G L M\end{array}$ & $\begin{array}{l}\text { Diet } 3 \\
15 \% G L M+E\end{array}$ & SEM & $P$ value \\
\hline Superoxide dismutase (\%) & $22.71^{b}$ & $33.91^{\mathrm{a}}$ & $40.48^{a}$ & 2.79 & 0.003 \\
\hline Glutathione peroxidase $(\mu \mathrm{g} / \mathrm{g})$ & $62.26^{b}$ & $81.53^{\mathrm{a}}$ & $89.17^{\mathrm{a}}$ & 4.38 & 0.005 \\
\hline Catalase $(\mathrm{mM} / \mathrm{ml} / \mathrm{min})$ & 0.006 & 0.002 & 0.003 & 0.001 & 0.643 \\
\hline
\end{tabular}

Means within a row with different letters are significantly different $(P<0.05)$

GLM Gliricidia leaf meal, $E$ exogenous enzyme 
Table 8 Chemical composition (\%) and energy (Kcal/kg) of Gliricidia leaf meal

\begin{tabular}{ll}
\hline Parameters & Quantity \\
\hline Dry matter & 93.03 \\
Crude protein & 24.75 \\
Crude fibre & 12.65 \\
Ash & 8.65 \\
Ether extract & 1.61 \\
Nitrogen-free extract & 45.37 \\
Tannin & 1.31 \\
Energy & 3840 \\
\hline
\end{tabular}

processed cocoa pod husk meal based diet and pawpaw leaf meal inclusive diet, respectively.

One of the major causes of retarded growth in livestock is oxidative stress. However, the use of herbal based antioxidants to ameliorate the stress is becoming popular [34]. Antioxidants significantly delay or prevent oxidation of lipids, protein, carbohydrates and DNA [35]. For instance, an antioxidant enzyme like glutathione peroxidase, superoxide dismutase and catalase can prevent oxidation either by stabilizing transition metal radicals such as $\mathrm{Fe}^{2+}$ or $\mathrm{Cu}^{+}$or by scavenging initiated free radicals such as superoxide and hydrogen peroxide, the most reactive free radical in vivo [36]. In this study, the 15\% GLM and $15 \%$ GLM $+\mathrm{E}$ based diets were found to promote the scavenging of superoxide ion by increasing superoxide dismutase activity. In the same trend, the higher plasma values of glutathione peroxidase, a catalyst for various peroxides degradation in rabbits fed 15\% GLM and 15\% GLM +E based diets compared to the control further revealed the antioxidant properties of the leaf meal in use in this study. This further confirms the use of GLM as safe feed ingredients in the diets of growing rabbit.

\section{Conclusion}

Dietary inclusion of GLM at 15\% of the diet had no effect on rabbits' performance at post-weaning period (35-63 day) but requires the use of multi-enzyme like the one used in this study to enhance performance at finishing period (63-91 days) and whole fattening period (35-91 d) without deleterious effects on the dry matter and crude protein digestibility. The 15\% GLM dietary inclusion with or without multi-enzyme had no deleterious effect on the rabbits' carcass cut, organ's integrity and the haematological indices; while triglyceride, cholesterol and LDL were reduced and the oxidative status of the rabbits was enhanced. Thus, the use of GLM + E could help to stem the overdependence on import duty feed ingredients used in rabbit feed formulation in this sub-Sahara Africa where the shortage of animal protein is endemic.

\section{Abbreviations}

AD: Apparent digestibility; AOAC: Association of Analytical Chemist; BW: Body weight; CP: Crude protein; DFI: Daily feed intake; DM: Dry matter; DWG: Daily weight gain; E: Multi-enzyme; FCR: Feed conversion ratio; GLM: Gliricidia leaf meal; GPx: Glutathione peroxidase; KEDTA: Potassium ethylene diamine tetraacetic acid; LDL: Low density lipoprotein;" SOD: Superoxide dismutase; SPSS: Statistical Package for Social Sciences

\section{Availability of data and materials}

The datasets used and/or analysed during the current study are available from the corresponding author on reasonable request.

\section{Authors' contributions}

This work was carried out in collaboration between all authors. ODO, SOA and JOA designed the study. ODO, SOA, ESA, OTD and DAO carried out the feeding trial and sample collection. ODO performed the statistical analysis. DAO carried out the blood analysis. ODO, JOA, SOA and DAO wrote the protocol and first draft of the manuscript. ODO and JOA managed the literature searches. All authors read and approved the final manuscript.

\section{Ethics approval}

All experimental procedures involving animals were conducted in accordance with Animal Experimental Guidelines provided by The Animal Research and Ethics Committee of The Agricultural Technology Department, The Federal Polytechnic, Ado Ekiti, Nigeria.

\section{Consent for publication}

Not applicable.

\section{Competing interests}

The authors declare that they have no competing interest.

\section{Publisher's Note}

Springer Nature remains neutral with regard to jurisdictional claims in published maps and institutional affiliations.

\section{Author details}

${ }^{1}$ Animal Science Department, Adekunle Ajasin University, Akungba Akoko, Nigeria. ${ }^{2}$ Animal Production and Health Department, The Federal University of Technology, Akure, Nigeria. ${ }^{3}$ Department of Agricultural Technology, The Federal Polytechnic, Ado Ekiti, Nigeria. ${ }^{4}$ Microbiology Department, The Federal University of Technology, Akure, Nigeria.

Received: 5 November 2017 Accepted: 27 September 2018 Published online: 06 October 2018

\section{References}

1. Oloruntola OD, Daramola OT, Omoniyi SO. Effect of forages on performance, carcass cuts and haematological profile of weaner rabbits. Arch Zootec. 2015;64(245):87-92.

2. Dhama K, Latheef SK, Manin S, Samad HA, Karthik K, Tiwari R, Khan RU, Alagawany M, Farag MR, Alam GM, Laudadio V, Vincenzo T. Multiple beneficial application and modes of action of herbs in poultry health and production. A review. Int J Pharmacol. 2015;11(3):152-76.

3. Valenzuela-Grijalva NV, Pinelli-Saavedra A, Muhlia-Almazan A, DominguezDiaz D, Gonzalez-Rios H. Dietary inclusion effects of phytochemicals as growth promoters in animal production. J Anim Sci Tech. 2017;59:8. https:// doi.org/10.1186/s40781-017-0133-9.

4. Amata IA. The effect of feeding Gliricidia leaf meal (GLM) on the haematological, serological and carcass characteristics of weaned rabbits in the tropics. Agric Biol J North America. 2010;1(5):1057-60.

5. Oloruntola OD, Ayodele SO, Agbede JO, Asaniyan EK. Performance and apparent digestibility of broiler starter fed diets containing Gliricidia sepium leaf meal. Asian J Bio Life Sci. 2016;5(1):97-102.

6. Agbede JO, Aletor VA. Evaluation of fish meal replaced with protein concentrate from Glyricidia in diets of broiler-chicks. Int J Poultry Sci. 2003;2(6):421-9. 
7. Akharaiyi F, Boboye B, Adetuyi FC. Antibacterial, phytochemical and antioxidant activities of the leaf extracts of Gliricidia sepium and Spathodec campanulata. World Appl Sci J. 2012;16(4):523-30.

8. Kiarie E, Romero LF, Nyachoti CM. The role of added feed enzymes on promoting gut health in swine and poultry. Nutr Res Rev. 2013;26:71-88 https://doi.org/10.1017/ S0954422413000048.

9. Ayodele SO, Oloruntola OD, Agbede JO. Effect of Alchornea cordifolia leaf meal inclusion and enzyme supplementation on performance and digestibility of rabbits. World Rabbit Sci. 2016;24:201-6.

10. Falcao-e-Cunha L, Castro-Solla L, Maertens L, Marounek M, Pinheiro V, Freire J, Mour JL. Alternatives to antibiotic growth promoters in rabbit feeding: a review. World Rabbit Sci. 2007;15:127-40.

11. Onasanya GO, Oke FO, Sanni TM, Muhammad Al. Parameters influencing haematological, serum and bio-chemical references in livestock animals under different management systems. Open J Vet Med. 2015;5:181-9.

12. El-Katcha MIY, Ismail EY, Soltan MA, El-Naggar MK. Effect of dietary probiotics supplementation on growth performance, immune response, some blood parameters and carcass quality of growing rabbits. Alexandria J Vet Sci. 2011;34:153-69.

13. Oloruntola OD, Ayodele SO, Agbede JO, Oloruntola DA. Effect of feeding broiler chickens with diets containing Alchornea cordifolia leaf meal and enzyme supplementation. Arch Zootec. 2016;65(252):489-98.

14. AOAC. Association of Official Analytical Chemistry, official methods of analysis 15 edition. Washington DC. 1990:69-88.

15. Makkar HPS, Goodchild MO. A bioassay for polyphenol (tannin in Vercauteren, J, Cheze, C, Dumon, M. C (Eds), proceeding of the international conference of polyphenols. Polyphenols Comm 1996: 96(1):197-198.

16. Fernandex-Carmona J, Blas E, Pascual JJ, Maertens L, Gidenne T, Xiccato G, Garcia $J$. Recommendations and guidelines for applied nutrition experiments in rabbits. World Rabbit Sci. 2003;13:209-28 https://doi.org/10.4995/wrs.2005.516.

17. Blasco A, Ouhayoun J, Masoero G. Harmonization of criteria and terminology in rabbit meat research. World Rabbit Sci. 1993;1:3-10 https:// doi.org/10.4995/wrs.1993.189.

18. Brunett N, Mathura K, Metivier KS, Holder RB, Brown G, Campbell M. An investigation into haematological and serum chemistry parameters of rabbits in Trinidad. World Rabbit Sci. 2003;14:175-87.

19. Rotruck JT, Pope AL, Ganther HE, Hafeman DG, Hoekstra WG. Selenium: biochemical role as a component of glutathione peroxidase. Sci. 1973;179:588-90.

20. Misra HP, Fridovich I. The univalent reduction of oxygen by flavins and quinines. J Biol Chem. 1972;247:188-92.

21. Aebi H. Catalase estimation. In: Bergmeyer HV, editor. Methods of enzymatic analysis. New York: Verlag Chemic; 1974. p. 673-84

22. EGRAN. Technical note: attempt to harmonize chemical analyses of feeds and faeces for rabbit feed evaluation. World Rabbit Sci. 2001;9(2):57-64.

23. Al-Harthi MA, El-Deek AA, Attia YA, Bovera F, Qota EM. Effect of different dietary level of mangrove (Laguncularia racemosa) leaves and spices supplementation on productive performance, egg quality, lipid metabolism and metabolic profiles in laying hens. Br Poult Sci. 2009;50:700-8.

24. Falcao-e-Cunha L, Reis J, Freire JB, Castro-Solla L. Effect of enzyme addition and source of fibre on growth and fibrolytic activities of growing-finishing rabbits. In: Proceedings of 8th World Rabbit Congress, September 7-10, 2004, Puebla, Mexico, vol. 2004. p. 1532-7.

25. Bimrew A. Effect of common feed enzymes on nutrient utilization of monogastric animals. Int J Biotech, Molecular Biol Res. 2014;5(4):27-34

26. Eiben CS, Gippert T, Godor-Surmann K, Podmaniczky B, Kustos K. Effect of dietary phosphorus reduction and phytase supplementation on growth of rabbits. In Proceedings of $9^{\text {th }}$ World Rabbit Congress. June 10-13, 2008 , Verona, Italy, 2008, p. 201.

27. Bedford MR. Exogenous enzymes in monogastric nutrition. Their current value and future benefits. Anim Feed Sci Tech. 2000;86:1-13.

28. Soetan $\mathrm{KO}$, Oyewole $\mathrm{OE}$. The need for adequate processing to reduce the anti-nutritional factors in plants used as human foods and animal feeds. A review African J Food Sci. 2009;3(9):223-32.

29. Yilkal T. Important anti-nutritional substances and inherent toxicants of feeds. Food Sci Quality Manag. 2015;36:40-7

30. Oloruntola OD, Ayodele SO, Agbede JO, Oloruntola DA, Ogunsipe MH, Omoniyi IS. Effect of Alchornea cordifolia leaf meal and enzyme supplementation on growth, haematological, immunostimulatory and serum biochemical response of rabbits. Asian J Bio Life Sci. 2016;5(2):190-5.

31. Adeyeye SA, Agbede JO, Aletor VA, Oloruntola OD. Processed cocoa (Theobroma cacao) pod husks in rabbit diet: effect on haematological and serum biochemical indices. Asian J Adv Agric Res. 2017;2(4):1-9. https://doi. org/10.9734/AJAAR/2017/36141.

32. Oloruntola OD, Ayodele SO. Pawpaw leaf meal and exo-enzyme in rabbit diet: effect on haematological and serum biochemical indices. Asian J Adv Agric Res. 2017;2(4):1-8. https://doi.org/10.9734/AJAAR/2017/36309.

33. Peter ML, Susan CEF. Interpretation of laboratory results. Australian Vet Pract. 1999;21(4):188-93.

34. Gupta S, Mediratta PK, Singh S, Sharma KK, Shukla R. Antidiabetic, antihypercholesterolaemic and antioxidant effect of Ocimum sanctum Linn. Seed oil Indian J Exp Bio. 2006:44:300-4.

35. Oboh G, Rocha JBT. Polyphenols in red pepper [Capsicum annuum var. aviculare (Tepin)] and their protective effect on some pro-oxidant induced lipid peroxidation in brain and liver. Eur Food Res Tech. 2007;225:239-47.

36. Afolabi AB, Oloyede Ol. Antioxidant properties of the extracts of Talinum triangulare and its effect on antioxidant enzymes in tissue homogenate of Swiss albino rat. Toxicol Int. 2014;21(3):307-13. https://doi.org/10.4103/0971-6580.155377.
Ready to submit your research? Choose BMC and benefit from:

- fast, convenient online submission

- thorough peer review by experienced researchers in your field

- rapid publication on acceptance

- support for research data, including large and complex data types

- gold Open Access which fosters wider collaboration and increased citations

- maximum visibility for your research: over $100 \mathrm{M}$ website views per year

At $\mathrm{BMC}$, research is always in progress.

Learn more biomedcentral.com/submissions 